\title{
Corporate Governance In The Lodging Industry: Special Case Of The Service Industry
}

Twila-Mae Logan, Florida International University, USA Doreen J. Gooden, Florida International University, USA Helen H. Simon, Florida International University, USA

\begin{abstract}
This paper examines the corporate governance structure of publicly traded hospitality firms and determines whether the governance structure selected by these firms is consistent with minimizing monitoring and bonding costs dictated by the complexity of the business models.
\end{abstract}

There is strong evidence that complex firms had larger board of directors, more outside board members, a greater fraction of CEO pay being variable, and more frequent occurrence of CEO/Chairman duality than simple firms. The results also present evidence of a positive relationship between firms that have the appropriate governance structures and the profitability and valuation of the firm.

Keywords: Corporate Governance; Profitability; Valuation; Hospitality Firms

\section{INTRODUCTION}

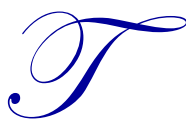

he hospitality industry has undergone changes in its business model through the 1990s and 2000s. For example, in the lodging sector, there has been significant consolidation in the industry, leaving a few large firms that operate in several markets - time share, budget hotels, full service, and luxury brands. Other major changes include purchases by private equity groups and innovative financing deals like real estate investment trust and its variants. The structure of the lodging industry is also quite complex and varied. The portfolio of hotels can include company-owned hotels, franchises, firms operated under management contracts, and time share (partial ownership) arrangements. Thus, business models in this industry may require different governance structures from other service industries.

The choice of corporate governance structure has implications for the management of the firm and well as firm value. Jensen and Meckling (1976) and Williamson (1979) viewed the firm as a nexus of contracts and argued that the firm is organized such that the transaction costs of these contracts are minimized. Faleye et al. (2011) found that outside board members increase the effectiveness of monitoring mangers but at the expense of weaker strategic advising. Larcker et al. (2011) found that government regulations that would appear to strengthen governance structures - executive pay, proxy access and staggered board - appear to reduce shareholders' wealth. Other researchers have investigated the relationship between ownership structure and firm value (see Morck, Shleifer, \& Vishny, 1988). The argument posed by these researchers suggests that the level of monitoring and bonding of management will provide the requisite incentives for managers to make decisions that maximize shareholder wealth and minimize the agency costs due to managerial entrenchment.

The focus of prior research on corporate governance structures was not on specific industries; few papers examined a particular industry. Theories have been developed and empirical work done assuming that there is uniformity in optimal governance structures across industries and firm characteristics. It is quite plausible that what is appropriate for a manufacturing firm is suboptimal for a financial firm or a service firm. Similarly, optimal 
governance structure may vary according to the size and complexity of the firm. Hence, having the optimal governance structure that will reduce agency costs and increase firm value and profitability is critically important for firms in the hospitality industry.

In this paper, we seek to determine whether the corporate governance structure selected by publicly traded lodging and gaming firms are consistent with minimizing monitoring and bonding costs dictated by the more complex business models within these firms.

\section{LITERATURE REVIEW}

Following the scandals in many companies in the U.S. and other parts of the world in the 1990s and 2000s, much attention is being placed on corporate governance. Having effective corporate governance systems in place is increasingly becoming a prerequisite for doing business both domestically and internationally. The Organization of Economic Cooperation and Development (OECD), for example, issued its "OECD Principles of Corporate Governance" in 1999. These principles are intended to assist member and non-member countries in evaluating and improving the legal, institutional, and regulatory framework for better corporate governance. Another international organization - the International Monetary Fund (IMF) - has mandated that corporate governance improvements be included in its debt-relief program. According to Ariff et al. (2007), corporate governance is a mechanism that fosters increased confidence in the market and the economy. Studies have shown that a good corporate governance system results in high corporate valuation and that good governance leads to a reduction in agency costs. Khancel (2007) found that firms with high growth opportunities and high intangible assets have stronger governance.

Alves and Barbot (2007) implied that governance structures for low-cost airlines are different from fullservice airlines. The rationale here is that low-cost airlines require small and nimble governance structure that allows management to make rapid changes as the environment evolves. Full-service airlines, with their complex business model, require a larger and more formal governance structure. We extend this study of the airline industry to the lodging industry to see whether complex hospitality firms have significantly different governance structures than do simple hospitality firms.

We considered two types of corporate governance structures - monitoring and bonding. Thus, we hypothesize that board size, number of outsiders, chairman/CEO duality, and board committees would be proxies for board oversight. That is, a larger board, greater number of outsiders, non duality, and the presence of audit and governance committees would be associated with greater monitoring of the CEO. We also posit that CEO tenure is a proxy for CEO turnover, which substitutes for labor market monitoring. We also hypothesize that the percentage of the CEO compensation - that is variable - could be a proxy for bonding as the greater the variable portion of the CEO's compensation, the more likely the CEO's action will be aligned with shareholders.

\section{Monitoring}

Studies have shown that the size of the board impacts the quality of corporate governance. Coles et al. (2008) argued that larger boards with more outsiders can be favorable for complex firms for two reasons. First, this board structure can provide for more extensive monitoring. Second, a larger and more diverse group of directors can provide the complex firms with a wider range of experiences/perspectives. Stulz (1988) posited that higher debt levels can act as an effective managerial control tool. Thus, Wen et al. (2002) and Abor (2007) found that a significantly larger board for higher leveraged firms is consistent with firms requiring greater monitoring. On the other hand, Jensen and Meckling (1976) and Jensen (1993) argued that smaller boards are more effective and profitable because they have a better monitoring system and that board effectiveness will decline as the board size increases above a moderate number. This latter argument would be consistent with the simpler firm having a smaller board.

Helland and Sykuta (2005) maintained that when boards have a higher proportion of outside directors, they monitor management more effectively. Forbes and Milliken (1999) argued that outside directors tend to view the responsibilities of the directors as different from those of management and that inside directors view their responsibilities as an extension of their managerial responsibilities. Brunninge et al. (2007) found that outside 
directors are instrumental in establishing strategic changes in organizations. Duchin et al. (2010) argued that outside directors are most beneficial to firm value when the cost of acquiring information about the firm is low. Thus, not all firms will experience higher valuation with more outside directors.

Dorata et al. (2008), Fama and Jensen (1983), and Abor (2007) stated that duality reduces board monitoring. This can lead to sub-optimal decision-making and a reduction in shareholders' wealth. Further, Darus and Mohamad (2011) held that CEO duality was more prevalent in Malaysian firms that suffered financial distress after the Asian financial crisis in 1997. Board decisions are not subject to much scrutiny when there is no separation of CEO and Chairman. Hence, the separation of the CEO and the chairman should allow firms with more complex business issues to make better business decisions.

\section{Bonding}

Jensen and Murphy (1990) argued that including a variable portion in the CEO compensation should help to align managerial interests with those of shareholders. Bonding through compensation packages often can be less costly and more effective than direct monitoring. Lippert and Williams (1995) provided some evidence that bonding through CEO compensation can operate as a substitute for, rather than the complement of, monitoring by the board of directors. Lippert and Mazur (1999) suggested that CEO compensation will vary depending on the type of firm. In their study of multinational corporations (MNC) and domestic firms (DC), they found that the CEOs of DC compensation had a stronger correlation with firm (equity) value than the CEOs of MNC. This difference they attribute to the greater investment opportunities of MNCs. Hence, firms that require greater levels of monitoring should structure their CEO pay with a greater percentage being variable.

\section{The Model}

Utilizing the literature on valuation, firm characteristics, and corporate governance structures, we developed a model that links firm characteristics and firm profitability/valuation. Firms are deemed to be complex or simple based on their size, scope of business, and financing choice. This partitioning of firms into simplex and complex is comparable to Alves and Barbot (2007) dividing their sample into full-service and low-cost airlines, as well as Coles' et al. (2008) definition of simple and complex firms. In this model, complex firms are large, rely on significant debt financing, and have several lines of business. Each firm then decides on a particular governance structure - informal or formal. A formal governance structure would include large boards with a significant number of independent/outside directors and, in general, more monitoring and bonding mechanisms. Conversely, an informal governance structure would have smaller boards and a larger percentage of inside directors. Thus, simple firms with informal governance structure and complex firms with formal governance structure should have higher valuation/profitability. On the other hand, simple firms with formal governance structures and complex firms with informal governance structure will result in low valuation/profitability (see Appendix A for schematic representation of the model).

\section{HYPOTHESES}

Based on the above, we present the first hypothesis $\mathrm{H}_{01}$ and the corresponding null $\mathrm{H}_{11}$ :

$\mathbf{H}_{01}$ : There are no differences between the governance structure of complex firms and simple firms in the hospitality industry.

$\mathbf{H}_{11}$ : There are differences between the governance structure of complex firms and simple firms in the hospitality industry.

Studies have shown that good corporate governance systems can reduce agency costs, resulting in higher corporate valuation. Khancel (2007) found a strong correlation between firms with high growth opportunities and those with stronger governance systems. Zahra and Pearce (1989) found a positive relationship between the percentage of outside directors and the performance of the firm. Yermach (1996) found that firms that separated the functions of the CEO and chairman traded at higher price-to-book multiples. De Andres et al. (2005) and Saikouras 
et al. (2007) found that firms with a greater number of directors had lower firm values. Further, Agrawal and Knoeber (1996) and Yermack (1996) found that lower firm value is associated with a greater number of outside directors. Duchin et al. (2010) argued that the relationship between firm value and outside director is dependent on the outside director's information-gathering costs. Thus, we present our second hypothesis:

$\mathbf{H}_{\mathbf{0 2}}$ : Firms with the appropriate corporate governance structures will not have higher levels of profitability than those with less appropriate corporate governance structures.

$\mathbf{H}_{12}$ : Firms with the appropriate corporate governance structures will have higher levels of profitability than those with less appropriate corporate governance structures.

\section{DATA AND METHODOLOGY}

We obtained financial and corporate governance data from COMPUSTAT and Corporate Library found the WRDS website for the years 2001-2010. We selected firms based on their primary SIC code 7011 - hotels and motels. Financial statement data were obtained from the COMPUSTAT database and board and CEO data were obtained from the Corporate Library database and supplemented by SEC proxy statements. The COMPUSTAT database produced several hundred firm years; however, the Corporate Library database had limited data, so our sample was reduced to 116 firm years comprising 21 different firms (see Appendix B for list of firms used).

We used factor analysis to identity a complexity variable (analogous to the advice variable in Coles et al., 2008). Leverage (long-term debt/total assets), sales, and number of business/geographical segments were used for the factor analysis. The factor analysis indicated that we needed two factors to measure complexity (factors with eigenvalues greater than or equal to 1 ). One factor was positively correlated with leverage and negatively correlated with number of segments, while the other factor was highly positively correlated with firm size as measured by total assets and weakly positively correlated with number of segments and leverage. A firm had multi segments if it had operations in different countries and/or if it operated in different business segments. Segment data were obtained from the COMPUSTAT database.

We partitioned the sample based on the factor scores. We computed the median value - the factor that was highly correlated with size. We selected this factor as it has a more intuitive interpretation; firms that are larger have more segments and are more levered, being the more complex firms. Complex firms were those whose factor scores were above the median and simple firms were those factor scores were below the median value ${ }^{1}$. The non parametric test - Wilcoxon Rank Sum - as well as the parametric two sample t-tests, were used to determine whether there were any differences in total board size, number of outsiders, and the percentage of insiders on the board, duality, percentage shareholding of insiders, and the percentage of CEO pay that is variable.

\section{RESULTS}

The results are presented in Table 1. Both the non-parametric and t-tests indicated that there are significant differences in total board size, and number of outsiders, percentage of inside directors, the percentage of shares held by insiders, percentage of the CEO pay that is variable, and duality between complex (1) vs. simple firms (0). That is, complex firms have larger boards than simple firms, as well as a large percentage of CEO pay that is variable. Also, the CEO and chairman are more likely the same person. The greater number of outsiders is also consistent with the argument presented in Helland and Sykuta (2005) and Forbes and Milliken (1999) - that outsiders are better monitors and advisors.

The more frequent occurrence of duality for complex firms would suggest less monitoring of the CEO by the board, greater agency costs, and less incentives for the CEO to act in the best interest of the shareholders (Fama \& Jensen, 1983; Jensen, 1983; Yermach, 1996; and Abor, 2007). However, the much higher levels of variable pay (64\% vs. 40\%) provide substantial incentives to the CEO to act in the best interest of shareholders. However, this is not entirely consistent with Jensen and Murphy (1990) who found that CEOs of smaller firms (assumed to be less

\footnotetext{
${ }^{1}$ This methodology is consistent with Coles et al. (2008), Guay 1999, and Gaver and Gaver (1993), as cited in Coles. 
complex) had a higher variable pay component. The simple firms had a higher percentage of the shares held by insiders.

Table 1: Non-Parametric And Parametric Test Of Differences In Board Composition And CEO Variable Pay Percentage Between Complex Firms (1) And Simple Firms (0)

\begin{tabular}{|c|c|c|c|c|c|c|c|c|c|}
\hline \multirow[t]{2}{*}{ Test } & \multicolumn{3}{|c|}{ Board Size } & \multicolumn{3}{|c|}{ \# of Outsiders } & \multicolumn{3}{|c|}{$\%$ of Insiders } \\
\hline & \multicolumn{2}{|c|}{ Score } & \multirow{3}{*}{$\begin{array}{l}\text { p-value } \\
<0.0001\end{array}$} & \multicolumn{2}{|c|}{ Score } & \multirow{3}{*}{$\begin{array}{l}\text { p-value } \\
<0.0001\end{array}$} & \multicolumn{2}{|c|}{ Score } & \multirow{3}{*}{$\frac{\text { p-value }}{0.0083}$} \\
\hline \multirow{2}{*}{ Wilcoxon } & 0 & 43.7 & & 0 & 42.2 & & 0 & 64.4 & \\
\hline & 1 & 70.5 & & 1 & 72.1 & & 1 & 49.4 & \\
\hline \multirow[t]{2}{*}{ t-test } & 0 & 8.1 & \multirow[t]{2}{*}{$<0.0001$} & 0 & 6.1 & \multirow[t]{2}{*}{$<0.0001$} & 0 & 0.25 & \multirow[t]{2}{*}{0.0051} \\
\hline & 1 & 9.9 & & 1 & 7.9 & & 1 & 0.20 & \\
\hline
\end{tabular}

\begin{tabular}{|c|c|c|c|c|c|c|c|c|c|}
\hline \multirow{4}{*}{$\begin{array}{l}\text { Test } \\
\text { Wilcoxon }\end{array}$} & \multicolumn{3}{|c|}{ Duality } & \multicolumn{3}{|c|}{ \% Pay Variable } & \multicolumn{3}{|c|}{ \% Shares Held By Insiders } \\
\hline & \multicolumn{2}{|c|}{ Score } & \multirow{3}{*}{$\frac{\text { p-value }}{0.0002}$} & \multicolumn{2}{|c|}{ Score } & \multirow{3}{*}{$\frac{\text { p-value }}{<0.0001}$} & \multicolumn{2}{|c|}{ Score } & \multirow{3}{*}{$\begin{array}{l}\text { p-value } \\
0.0069\end{array}$} \\
\hline & 0 & 48.0 & & 0 & 39.1 & & 0 & 64.5 & \\
\hline & 1 & 67.0 & & 1 & 66.3 & & 1 & 49.3 & \\
\hline \multirow[t]{2}{*}{ t-test } & 0 & 0.5 & \multirow[t]{2}{*}{0.0002} & 0 & 0.40 & \multirow[t]{2}{*}{$<0.0001$} & 0 & 0.38 & \multirow[t]{2}{*}{0.0147} \\
\hline & 1 & 0.8 & & 1 & 0.64 & & 1 & 0.26 & \\
\hline
\end{tabular}

Score for t-test represents the mean of the following variables: board size, number of outsiders, percentage of insiders on board, duality, percentage of the CEO pay that is variable and percentage of shares held by insiders.

There are two possible explanations. First, the simpler firms have less independent monitoring (fewer outside directors and a higher percentage of insider directors), so aligning the welfare of insiders with that of shareholders becomes more important. Second, complex firms are larger, so even if these insiders had the same number of shares (as the insiders of simple firms), the percentage ownership would be lower.

Multiple regressions were used to determine the relationship between firm complexity and monitoring and bonding mechanisms. The dependent variable was the factor score ${ }^{2}$. The results from the regressions are presented in Table 2. Board composition was measured using total number of directors (board size), number of outsiders, and percentage of board members that are insiders. The regressions were generally consistent with the univariate results. That is, complex firms had significantly larger boards and a greater number of outside directors. However, complex and simple firms have basically the same percentage of inside board members when other variables are held constant.

Regardless of how board composition is measured, complex firms were more likely to structure CEO pay with a higher variable component, have higher CEO turnover, older CEOs, and CEOs as chairmen of the board of directors. More complex firms appear to have higher CEO turnover evidenced by the negative and significant coefficient on CEO tenure variable. One possible explanation for the higher CEO turnover would be to reduce the agency costs associated with entrenchment of long serving CEOs. Alternatively, the higher CEO turnover could also be evidence of greater labor market monitoring where poor performing CEOs have a greater probability of losing their jobs (Jensen \& Murphy, 1990).

Consistent with the univariate results, the coefficient on the duality variable was positive and highly significant; that is, a more complex firm had the CEO and Chairman as the same person. This would appear to be counterintuitive as duality implies less monitoring. However, the complex firms counter the negative impact of duality by having larger boards and more outside directors as monitoring mechanisms. The complex firms also use the bonding mechanism of having a larger component of CEO's compensation as a variable. The negative and significant coefficient on CEO tenure could indicate that more complex firms are more likely to oust nonperforming CEOs than simpler firms. Simpler firms appear to rely more on the separation of chairman and CEO as a tool to monitor the actions of the CEO.

\footnotetext{
${ }^{2}$ The regressions were also run using the zero/one dummy variable as the dependent variable. The results are essentially the same but with lower $\mathrm{R}^{2}$
} 
Table 2: Multiple Regressions Of The Dependent Variable Complexity With Board Composition And CEO Characteristics

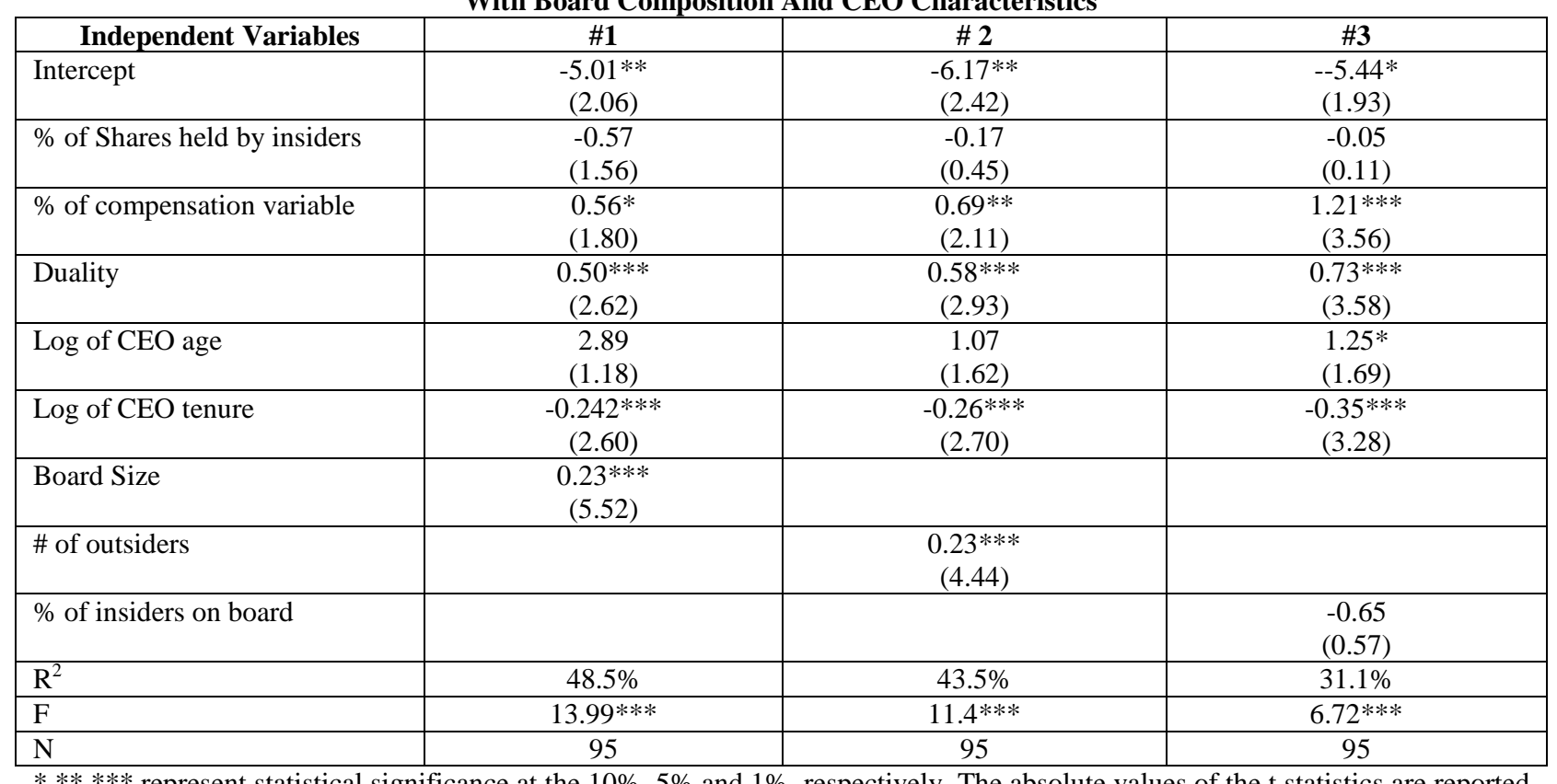

$*, * *, * * *$ represent statistical significance at the $10 \%, 5 \%$ and $1 \%$, respectively. The absolute values of the $\mathrm{t}$ statistics are reported in parentheses.

Based on the results from the Wilcoxon Rank Sum, the two sample t-tests, and the multiple regressions, we are able to reject the first hypothesis $-\mathrm{H}_{01}$ - that there are no differences in corporate governance structures for complex and simple firms. We can then conclude that more complex firms in the hospitality industry have different governance structures than do simpler hospitality firms.

The linear discriminant function classified the firms into complex or simple based on the following characteristics: percentage of shares held by insiders, percentage of the CEO pay that is variable, duality, CEO's age and tenure, as well as board size, number of outsiders, or the percentage of insiders on the board. This classification was then compared with the original one based on the factor from the analysis.

Based on the linear discriminant function, we were able to identify those firms that were correctly classified as simple or complex by both methods. We also identified those that were misclassified;-that is, firms that were classified as complex by one method and simple by the other method and vice versa. Firms that were correctly classified were considered to have the optimal monitoring/bonding mechanisms and those firms that were misclassified as having sub-optimal monitoring/bonding mechanisms.

The results from the discriminant analysis are provided are Table 3. The discriminant function did a better job of classifying the complex firms correctly. Using board size as a measure of board composition, $79 \%$ of the complex and simple firms were correctly classified. Using the number of outsiders $81 \%$ and $79 \%$ of complex and simple firms were classified correctly, while the percentage of insider measure classified $83 \%$ and $73 \%$ of complex and simple firms correctly.

Table 3: Percentage Of Firm Correctly Classified As Complex

Or Simple Using On A Linear Discriminant Function Based On Board Composition And Governance Variables

\begin{tabular}{|l|c|c|c|}
\hline & Board Size & \# Of Outsiders & \% Of Insiders \\
\hline Complex & $79.2 \%$ & $81.3 \%$ & $83.3 \%$ \\
\hline Simple & $79.2 \%$ & $79.2 \%$ & $72.9 \%$ \\
\hline Wilks' Lambada & $0.60 * * *$ & $0.60 * * *$ & $0.64 * * *$ \\
\hline
\end{tabular}

*** significant at the $1 \%$ level 
We used the classifications based on the discriminant analysis using outsiders as a measure of board composition $^{3}$ to compute the means and median of the market-to-book value, return on equity (ROE), and return on assets (ROA). We use ROE and ROA to measure the firm's profitability and market-to-book value as a measure of the firm's valuation. Market-to-book values and their variants have been used extensively in the literature to measure firm value (De Andres et al., 2005; Fich and Shivdasani, 2006). The results in Table 4 indicate that, in general, the correctly classified firms had higher valuation and profitability measures. The only exception was the mean ROA for the correctly classified complex firms; it was lower than the incorrectly classified ones. However, the median ROA for the complex firms was higher than the incorrectly classified ones.

Table 4: Descriptive Statistics Of The Firms That Were Classified Correctly And Incorrectly By The Discriminant Function

Simple Firms

\begin{tabular}{|l|c|c|c|c|}
\hline & \multicolumn{2}{|c|}{ Correctly Classified } & \multicolumn{2}{c|}{ Incorrectly Classified } \\
\hline & Mean & Median & Mean & Median \\
\hline Market-to-book & -0.10 & 1.44 & -3.26 & 1.34 \\
\hline Return on Assets & $4.3 \%$ & $2.5 \%$ & $3.4 \%$ & $0.2 \%$ \\
\hline Return on Equity & $1.1 \%$ & $5.0 \%$ & $-17.9 \%$ & $0.2 \%$ \\
\hline
\end{tabular}

Complex Firms

\begin{tabular}{|l|c|c|c|c|}
\hline & \multicolumn{2}{|c|}{ Correctly Classified } & \multicolumn{2}{c|}{ Incorrectly Classified } \\
\hline & Mean & Median & Mean & Median \\
\hline Market-to-book & 3.57 & 3.23 & 3.04 & 1.64 \\
\hline Return on Assets & $1.4 \%$ & $3.1 \%$ & $4.3 \%$ & $1.0 \%$ \\
\hline Return on Equity & $4.0 \%$ & $11.0 \%$ & $-1.8 \%$ & $-1.3 \%$ \\
\hline
\end{tabular}

Univariate statistics were used to test whether there are any differences between the market-to-book value, ROE and ROA for the firms that were correctly classified and those that were incorrectly classified. We used nonparametric tests, as the number of firms in the misclassified cells is small. The results are shown in Tables 5 and 6.

Although the market book values were higher for the correctly classified firms, there were no significant differences between the two groups based on the Wilcoxon Rank Sum or the median tests. The ROA and ROE were significantly larger for both the complex and simple firms that were correctly classified vis a vis those firms that were incorrectly classified using the median tests. The higher profitability for firms that have the appropriate governance structure is similar to results reported in Zahra and Pearce (1989) and Khancel (2007), indicating higher firm value/profitability with better corporate governance. However, our results are not consistent with De Andres et al. (2005), Staikouras et al. (2007), Agrawal \& Knoeber (1996), and Yermack (1996), as they all found lower profitability/value with stronger governance mechanisms. It is possible to argue, however, that the latter papers had a significant number of simple firms where less stringent corporate governance structures are more appropriate.

Using the classifications from the linear discriminant function and the factor analysis variable, we can reject the second hypothesis that there are no differences in profitability measures between firms that were correctly classified and those that were misclassified. Thus, we have some evidence that there is a positive relationship between firms that have the appropriate governance structures and the profitability of the firm.

\footnotetext{
${ }^{3}$ Using number of board size and percentage of insider directors gave essentially the same results.
} 
Table 5

Non-Parametric Tests Of Differences In Profitability Between Simple Firms That Were Classified As Simple (1) Based The Discriminant Functions And Those That Were Classified As Complex (0) By The Discriminant Function

\begin{tabular}{|c|c|c|c|c|c|c|c|c|c|}
\hline Test & \multicolumn{3}{|c|}{ Market-to-book } & \multicolumn{3}{|c|}{ ROA } & \multicolumn{3}{|c|}{ ROE } \\
\hline & \multicolumn{2}{|c|}{ Score } & p-value & \multicolumn{2}{|c|}{ Score } & p-value & \multicolumn{2}{|c|}{ Score } & p-value \\
\hline \multirow[t]{2}{*}{ Wilcoxon } & 0 & 20.1 & \multirow[t]{2}{*}{0.1347} & 0 & 20.5 & \multirow[t]{2}{*}{0.1580} & 0 & 18.9 & \multirow[t]{2}{*}{$0.0794 *$} \\
\hline & 1 & 25.7 & & 1 & 25.6 & & 1 & 26.0 & \\
\hline \multirow[t]{2}{*}{ Median } & 0 & 0.5 & \multirow[t]{2}{*}{0.5000} & 0 & 0.3 & \multirow[t]{2}{*}{$0.0798^{*}$} & 0 & 0.2 & \multirow[t]{2}{*}{$0.0174 * *$} \\
\hline & 1 & 0.5 & & 1 & 0.6 & & 1 & 0.6 & \\
\hline
\end{tabular}

Non-Parametric And Parametric Test Of Differences In Profitability Between Complex Firms That Were Classified As Simple (0) Based The Discriminant Functions And Those That Were Classified As Complex (1) By The Discriminant Function

\begin{tabular}{|c|c|c|c|c|c|c|c|c|c|}
\hline Test & \multicolumn{3}{|c|}{ Market-to-book } & \multicolumn{3}{|c|}{ ROA } & \multicolumn{3}{|c|}{ ROE } \\
\hline & & & p-value & & & p-value & & & p-value \\
\hline \multirow[t]{2}{*}{ Wilcoxon } & 0 & 20.4 & \multirow[t]{2}{*}{0.2432} & 0 & 23.2 & \multirow[t]{2}{*}{0.3755} & 0 & 19.1 & \multirow[t]{2}{*}{$0.0872 *$} \\
\hline & 1 & 23.7 & & 1 & 24.8 & & 1 & 25.9 & \\
\hline \multirow[t]{2}{*}{ Median } & 0 & 0.4 & \multirow[t]{2}{*}{0.2642} & 0 & 0.3 & \multirow[t]{2}{*}{$0.0798 *$} & 0 & 0.3 & \multirow[t]{2}{*}{$0.0798^{\prime}$} \\
\hline & 1 & 0.5 & & 1 & 0.6 & & 1 & 0.6 & \\
\hline
\end{tabular}

*significant at the $10 \%$ level $* *$ significant at the $5 \%$ level

\section{CONCLUSION}

Firms in the hospitality industry are faced with the challenge of being both labor and capital intensive. The typical service firm is usually labor intensive, but generally does not require a large amount of capital (fixed assets). A typical manufacturing firm that requires a great deal of capital is usually not labor intensive. In addition, the services provided by hospitality firms are mostly discretionary; hence, the demand for these services will fall a substantial amount during periods of low economy activity. Therefore, it is imperative that firms in the hospitality industry adopt corporate governance structures that will minimize agency costs and maximize the firm's ability to make value-creating decisions.

We selected a sample of publicly traded hospitality firms and partitioned them into complex and simple firms using the firm's financing decision, size, and the number of business segments. We had strong evidence that complex firms had larger board of directors, more outside board members, greater fraction of CEO pay being variable, and more frequent occurrence of CEO/Chairman duality than simple firms. We did not find that there were significant differences in the fraction of insider directors between complex and simple firms.

Further analysis of the data revealed that complex firms, with corporate governance structures that were associated with simple firms, had significantly lower levels of profitability measured, return on assets, and return on equity, and lower - but not significantly lower - valuation based on market-to-book value. Similarly, simple firms that had corporate governance structure more suitable for complex firms also had lower market-to-book value and significantly lower return on equity and return on assets.

\section{AUTHOR INFORMATION}

Dr. Twila-Mae Logan graduated from The Ohio State University with a PhD in Business Administration majoring in Finance and a minor in Economics. She has taught at The University of The West Indies (Kingston, Jamaica), Nova Southeastern University (Fort Lauderdale, Florida) and Messiah College (Grantham, Pennsylvania). She is currently a Clinical Assistant Professor of Finance at the Chaplin School of Hospitality and Tourism Management at Florida International University (North Miami, Florida). E-mail: thogan@fiu.edu

Dr. Doreen J. Gooden is a Senior Instructor in the Management and International Business Department at Florida International University. Her research interest includes transformational leadership practices, cultural values, foreign direct investment in emerging markets, corporate governance, and ground-based versus electronic-based instructional delivery. Her work has been published in the International Business \& Economic Research Journal, American Journal of Business Education, Employee Responsibilities and Rights Journal and the New Horizons in 
Adult Education Journal as well as in many conference proceedings. Dr. Gooden is a member of the Academy of Management, Academy of International Business and the Strategic Management Society. E-mail: goodend@fiu.edu (Corresponding author)

Dr. Helen Simon is active in the academic community and is the President of Personal Business Management Services, LLC, an investment advisory firm in the State of Florida. She has over 20 years of experience in the financial services industry. She is actively involved in research in the areas of market prediction models, behavioral finance and financial planning. She has presented papers at a variety of professional conferences and has authored publications in The Journal of Financial Planning, The Journal of Applied Management and Entrepreneurship, The International Review of Research in Open and Distance Education and The Business, Education \& Technology Journal and is a free-lance writer for Investopedia.com. E-mail: simonh@fiu.edu

\section{REFERENCES}

1. Abor, J. (2007). Corporate governance and financing decisions of Ghanaian listed firms. Governance, 7 (1), 83-92.

2. Agrawal, A., \& Kneober, C. (1996). Firm performance and mechanisms to control agency problems between managers and shareholders. Journal of Finance and Quantitative Analysis, 31, 377-401.

3. Alves, C.F., \& Barbot, C. (2007). Do low cost carriers have different corporate governance models? Journal of Air Transport Management, 13, 116-120.

4. $\quad$ Ariff, A., Ibrahi, M., \& Othman, R. (2007). Determinants of firm level governance: Malaysian evidence. Corporate Governance, 7 (5) 562-573.

5. Berger, P., Ofek, E., \& Yermack, D. (1997). Managerial entrenchment and capital structure decisions. Journal of Finance, 52 (4), 1411-38.

6. Brunninge, O., Nordqvist, M., \&Wiklund, J. (2007). Corporate governance and strategic change in SMEs: The effects of ownership, board composition and top management teams. Small Business Economics, 29, 295-308.

7. Coles, J, Daniel, N., \& Naveen, L. (2008). Boards: Does one size fit all? Journal of Financial Economics, 87, 329-356.

8. Darus, F., \& Mohamad, A. (2011). Corporate governance and corporate failure in the context of agency theory. The Journal of American Academy of Business, 17 (1), 125-132.

9. De Andres, P., Azofra, V., \& Lopez, F. (2005). Corporate governance in OECD countries: Size, composition, functioning and effectiveness. Corporate Governance, 13, 197-210.

10. Dorata, N., \& Petra, S. (2008). CEO duality and compensation in the market for corporate control. Managerial Finance, 34 (5), 343-353.

11. Duchin, R., Matsusaka, J., \& Ozbas, O. (2010). When are outside directors effective? Journal of Financial Economics, 96, 195-214.

12. Faleye, O., Hoitash, R., \& Hoitash, U. (2011). The cost of intense board monitoring. Journal of Financial Economics, 101, 160-181.

13. Fich, E.M., \& Shivdasani, A. (2006). Are busy boards effective monitors? Journal of Finance, 61 (2) 689724.

14. Forbes, D., \& Milliken, F. (1999). Cognition and corporate governance: Understanding board of directors as strategic decision-making groups. Academy of Management Review, 24 (3), 489-505.

15. Fama, E. F., \& Jensen, M.C. (1983). Separation of ownership and control. Journal of Law and Economics, 26(2), 301.

16. Jensen, M. (1993). The modern industrial revolution, exit, and the failure of internal control systems. Journal of Finance, 48, 831-880.

17. Jensen, M., \& Meckling, W. (1976). Theory of the firm: Managerial behavior, agency costs and ownership structure. Journal of Financial Economics, 3, 305-360.

18. Jensen, M. C., \& Murphy, K. J. (1990). Performance pay and top-management incentives. The Journal of Political Economy, 98(2), 225.

19. Klapper, L., \& Love, I. (2003). Corporate governance, investor protection, and performance in emerging markets. Journal of Corporate Finance, 10 (5) 703-728. 
20. Khanchel, I (2007). Corporate governance: measurement and determinant analysis. Managerial Auditing Journal, 22 (8), 740-760.

21. Lacker, D., Ormazabal, G., \&Taylor, D. (2011). The market reaction to corporate governance regulation. Journal of Financial Economics, 101, 431-448.

22. Lippert, R., \& Manzur, R. (1999). Multinationality, CEO compensation, and corporate governance: Some empirical evidence. Managerial Finance, 25 (10), 1-12.

23. Lippert, R., \&William, M. (1995). Monitoring versus bonding: Shareholder rights and management compensation. Financial Management, 24 (3), 54-63.

24. Morck, R., Shleifer, A., \& Vishny, R. W. (1988). Management ownership and market valuation: An empirical analysis. Journal of Financial Economics, 20(1,2), 293.

25. Staikouras, P., Staikouras, C., \& Agoraki, M. (2007). The effect of board size and composition on European bank performance. European Journal of Law and Economics, 23,1-27.

26. Stulz, R. M. (1988). Managerial control of voting rights: Financing policies and the market for corporate control. Journal of Financial Economics, 20(1,2), 25.

27. Wen, Y., Rwegasir, K, \& Bilderbeek, J (2002). Corporate governance and capital structure decisions of Chinese listed firms. Corporate Governance: An International Review, 10 (2), 75-83.

28. Williamson, O. (1979). Transaction-cost economics: The governance of contractual relations. Journal of Law and Economics, 22, 3-61. 


\section{APPENDIX A}

The Model

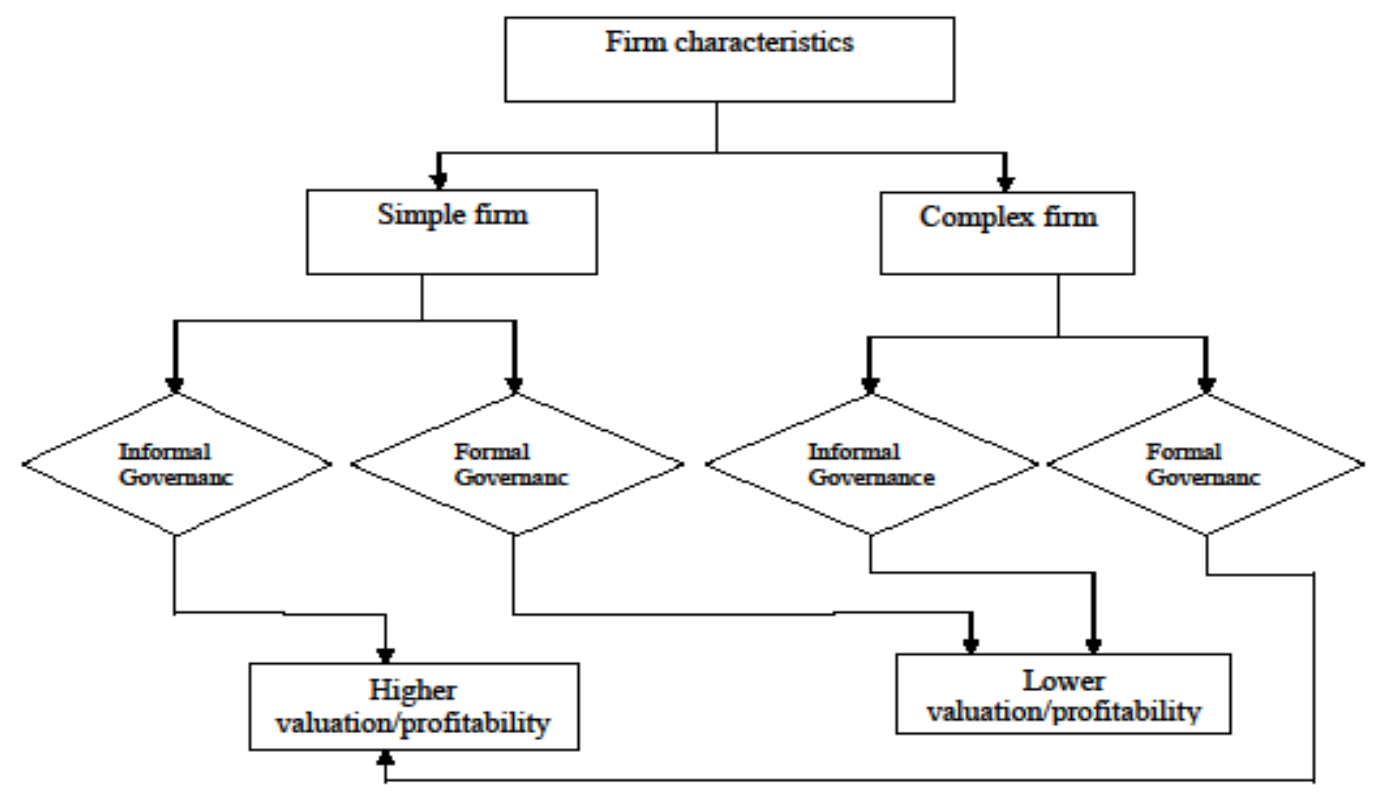




\section{APPENDIX B}

\section{List Of Hospitality Firms}

Ashford Hospitality Trust

Ameristar Casinos Inc.

Ceasars Entertainment Corp.

Choice Hotels Intl. Inc.

Century Casinos Inc.

Dover Downs Gaming \& Entmt.

Gaylord Entertainment Co.

Great Wolf Resorts Inc.

Hyatt Hotel Corp.

Isle Of Capri Casinos Inc.

Las Vegas Sands Corp.

Marriott Intl. Inc.

Monarch Casino \& Resort Inc.

Marcus Corp.

MGM Mirage

Morgans Hotel Group Co.

Pinnacle Entertainment Inc.

Sunstone Hotel Investors Inc.

Wyndham International Inc.

Starwood Hotels \& Resorts Wrld.

Wynn Resorts Ltd. 